\title{
PERAN PERAWAT DALAM UPAYA MEMUTUS RANTAI INFEKSI DI RUMAH SAKIT
}

\author{
Niken Malinda Putri \\ nikenmalindaputri01@gmail.com
}

\section{Latar Belakang}

Rumah Sakit sebagai salah satu institusi kesehatan mempunyai peran penting dalam melakasanakan upaya kesehatan secara berdaya guna, dan berhasil guna dengan mengutamakan upaya penyembuhan dan pemuihan yang dilaksanakan secara serasi dan terpadu dengan upaya peningkatan dan pencegahan serta melaksanakan upaya rujukan (Depkes RI, 2007).

Rumah sakit sebagai tempat pengobatan, juga merupakan sarana pelayanan kesehatan yang dapat mmenjadi sumber infeksi dimana orang sakit dirawat dan ditempatkan dalam jarak yang dekat. Infeksi nosokomial dapat terjadi pada penderita, tenaga kesehatan dan juga setiap orang datang ke rumah sakit. Infeksi yang ada di pusat pelayanan kesehatan ini dapat ditularkan atau diperoleh melalui petugas kesehatan, orang sakit, pengunjung yang berstatus karier atau karena kondisi rumah sakit (Darmadi, 2008). Kerugian yang ditimbulkan akibat infeksi ini adalah lamanya rawat inap yang tentunya akan membutuhkan biaya yang lebih banyak dai perawatan normal bila tidak terkena infeksi nosokomial (Edhie, 2010).

Presentase infeksi rumah sakit di rumah sakit dunia mencapai 9\% (variasi 3-21\%) atau lebih 1,4 juta pasien rawat inap dirumah sakit seluruh dunia mendapatkan infeksi rumah sakit. Suatu penelitian yang dilakukan WHO menunjukkan bahwa sekitar 8,7\% dari 55 rumah sakit dari 14 negara yang berasal dari Eropa, Timur Tengah, Asia Tenggara dan pasifik menunjukkan adanya infeksi rumah sakit dan Asia Tenggara sebanyak 10,0\% (Nugraheni, 2012).

Penyakit infeksi adalah penyakit yang disebabkan oleh agen biologi (virus, bakteri, parasit). Penyakit infeksi masih merupakan penyebab utama tingginya angka kesakitan dan kematian di dunia. Pada umumnya, penyakit infeksi lebih banyak terjadi di negara berkembang daripada di negara maju termasuk Indonesia. Penyakit infeksi di Indonesia masih termasuk dalam sepuluh penyakit terbanyak dengan frekuensi yang cukup tinggi (Lapau, B, 2012:253). Infeksi nosokomial atau Hospital Acquired Infections adalah infeksi yang didapatkan di rumah sakit dan timbul sesudah 72 jam perawatan pasien rawat inap. 
Upaya pencegahan dan pengendalian infeksi dengan cara memutus rantai penularan infeksi merupakan cara yang paling mudah untuk mencegah penularan penyakit infeksi, tetapi hasilnya bergantung pada ketaatan petugas dalam melaksanakan prosedur yang telah ditetapkan. (Kemenkes RI, 2011), (KARS, 2012).

Perawat selain dalam memberikan asuhan pelayanan keperawatan, perawat juga dapat berperan untuk memutus rantai infeksi baik di rumah sakit, puskesmas ataupun tempat perkerjaan lainnya. Perawat mencegah terjadinya infeksi dengan cara memutuskan rantai penularan infeksi (Craven \& Hirnle, 2007). Untuk itu dalam kajian ini akan dibahas bagaimana peran perawat dalam upaya memutus rantai infeksi yang berada di rumah sakit.

\section{Metode}

Metode yang saya gunakan dalam membuat kajian ini adalah metode lietrasi. Metode literasi adalah metode dengan membaca dan mengumpulkan informasi serta memahaminya. Literature yang saya baca berupa jurnal maupun buku atau e-book. Dari metode literasi ini saya dapat mengetahui maksud dan tujuan memutus rantai infeksi serta arti dari infeksi nosokomial. Saya juga dapat mengetahui peran perawat sebagai tenaga medis dalam mengendalikan pemutusan rantai infeksi dan dampak apa yang ditimbulkan baik itu bagi pasie, perawat itu sendiri dan bahkan bagi rumah sakit tempat perawat tersebut bekerja.

\section{Hasil}

Hasil yang saya dapatkan dalam membuat kajian ini dengan metode literature berupa dampak apa saja yang ditimbulkan oleh infeksi tersebut, faktor-faktor apa saja yang menyebabkan infeksi tersebut. Infeksi yang terjadi di rumah sakit ataupun infeksi nosokomial dapat ditemukan dari cairan tubuh pasien seperti darah, air liur, serum ataupun lain sebagainya, terdapat juga diperalatan-peralatan rumah sakit seperti benda tajam berupa pisau bedah, suntik, gunting dan lain sebagainya. Adapun peralatan lainnya berupa sarung tangan, masker, apron/celemek dan lain sebagainya. Oleh karena itu peralatan yang berada dirumah sakit harus dibuang ke tempat sampah khusus dan harus di sterilkan dengan benar ataupun disinfektan.

Selain dari hal tersebut infeksi juga didapat dari lingkungan yang tidak bersih. Untuk itu peran tenaga medis sangat dibutuhkan untuk memutus rantai infeksi tersebut. Sesuai dengan apa yang telah dinyatakan oleh Kemenkes RI (2011), KARS ( 2012) bahwa upaya 
pencegahan dan pengendalian infeksi dengan cara memutus rantai penularan infeksi merupakan cara yang paling mudah untuk mencegah penularan penyakit infeksi, tetapi hasilnya bergantung pada ketaatan petugas dalam melaksanakan prosedur yang telah ditetapkan.

Dari jurnal yang saya baca bahwa dampak yang dapat ditimbulkan berupa kerugian yang dialami oleh pasien, perawat dan rumah sakit. Adapun kerugian yang dialami pasien berupa semakin bertambah sakitnya pasien yang menyebabkan pasien harus lebih lama dirawat di rumah sakit yang menyebabkan biaya semakin mahal, selain itu juga dapat menyebabkan kematian bila infeksi terjadi semakin parah atau serius. Untuk perawat sendiri dapat kehilangan pekerjaan akibat efek infeksi yang tertular ke tubuh perawat, menurunnya kualitas pelayanan asuhan keperawatan, berkurangnya tenaga pekerja serta juga dapat menimbulkan kematian. Untuk rumh sakit sendiri rumah sakit akan mendapat citra yang buruk karena tidak dapat menghindari penanggulangan penyebaran infeksi yang membuat kualitas pelayanan menjadi buruk.

Karena itu betapa pentingnya peran tenaga medis di rumah sakit, terutama peran perawat. Karena perawat paling sering berkontak dengan pasien yang dimana salah satu penyebaran virus ataupun bakteri berasal dari pasien. Untuk itu dibutuhkan ketaatan dalam melaksanakannnya serta pengetahuan dan ketrampilan.

\section{Pembahasan}

Rumah sakit sebagai tempat pengobatan, juga merupakan sarana pelayanan kesehatan yang dapat mmenjadi sumber infeksi dimana orang sakit dirawat dan ditempatkan dalam jarak yang dekat. Infeksi nosokomial dapat terjadi pada penderita, tenaga kesehatan dan juga setiap orang datang ke rumah sakit. Infeksi yang ada di pusat pelayanan kesehatan ini dapat ditularkan atau diperoleh melalui petugas kesehatan, orang sakit, pengunjung yang berstatus karier atau karena kondisi rumah sakit (Darmadi, 2008). Kerugian yang ditimbulkan akibat infeksi ini adalah lamanya rawat inap yang tentunya akan membutuhkan biaya yang lebih banyak dai perawatan normal bila tidak terkena infeksi nosokomial (Edhie, 2010). Penyakit infeksi masih merupakan salah satu masalah kesehatan di dunia, termasuk Indonesia. Ditinjau dari asal atau didapatnya infeksi dapat berasal dari komunitas (Community Acquired Infection) atau berasal dari lingkungan pelayanan kesehatan atau klinik. 
Penyakit infeksi adalah penyakit yang disebabkan oleh agen biologi (virus, bakteri, parasit). Penyakit infeksi masih merupakan penyebab utama tingginya angka kesakitan dan kematian di dunia. Pada umumnya, penyakit infeksi lebih banyak terjadi di negara berkembang daripada di negara maju termasuk Indonesia. Penyakit infeksi di Indonesia masih termasuk dalam sepuluh penyakit terbanyak dengan frekuensi yang cukup tinggi (Lapau, B, 2012:253). Infeksi nosokomial merupakan penyebab penting tingginya morbiditas, mortalitas, dan masalah ekonomi. Bakteri yang berasal dari lingkungan rumah sakit dapat menyebabkan infeksi dan memiliki risiko tinggi mengalami infeksi nosokomial. (Widyaningsih, R. dan Buntaran, L. 2012:13).

Infeksi nosokomial atau Hospital Acquired Infections (HAI) adalah infeksi yang didapatkan di rumah sakit dan timbul sesudah 72 jam perawatan pasien rawat inap. Infeksi nosokomial menyebar melalui alat-alat medis serta fasilitas atau peralatan di rumah sakit. Infeksi akibat terpapar bakteri di rumah sakit (nosokomial) sering menyerang dan menyebab Di seluruh dunia, infeksi nosokomial terjadi dengan angka kejadian sebanyak $10 \%$ pada pasien rawat inap di rumah sakit yaitu sebanyak 1,4 juta terinfeksi setiap tahun.kan infeksi saluran kemih, saluran nafas bawah, serta aliran darah (Amirullah, 2012).

Dalam pelayanan keperawatan, terinfeksi merupakan masalah yang sangat serius sehingga memerlukan perhatian yang sangat besar dalam penatalaksanaan. Prinsip umum yang harus diperhatikan adalah menjaga agar pasien tidak terinfeksi, pasien yang terinfeksi tidak tertular oleh mikroorganisme yang lain, pasien yang terinfeksi tidak menjadi sumber penularan bagi pasien yang lain, dan menjaga infeksi jangan sampai berkembang dan menjadi lebih parah (Stevens, 2000).

Pasien dalam lingkungan perawatan kesehatan berisiko terkena infeksi karena daya tahan tubuh yang menurun, meningkatnya pajanan terhadap jumlah dan jenis penyakit yang disebabkan oleh mikroorganisme dan prosedur invasif. Dengan cara mempraktikkan teknik pencegahan dan pengendalian infeksi, perawat dapat menghindarkan penyebaran mikroorganisme terhadap pasien (Potter \& Perry, 2005).

Untuk itu perawat dituntut berperan dalam mencegah infeksi nosokomial dan memutus rantai infeksi, karena jika hal ini dibiarkan maka infeksi yang terkena pada pasien dapat merugikan secara ekonomi seperti pasien akan sakit makin lama yang mengakibatkan bertambahnya biaya pengobatan pada rumah sakit, bahkan selain itu dapat juga menyebabkan kematian, sedangkan kerugian pada perawat sendiri berupa ke tidak ekefektifan pelayanan yang diberikan, kurangnya tenaga kerja di rumah sakit karena perawat harus absen dari pekerjaan dikarenakan sakit dan jika penyakit yang disebabkan oleh infeksi penularan 
nosokomial semakin parah dapat menyebabkan kematian. Hal ini juga dapat berdampak pada citra rumah sakit tentang nilai pelayanan asuhan keperawatan.

Adapun cara yang dilakukan perawat dalam memutus rantai infeksi dapat berupa :

1. Hand hygiene

Hand hygiene adalah istilah yang digunakan untuk mencuci tangan. Pada tahun (2009), Worrld Health Organization (WHO) mencetuskan global patient safety challage dengan clean care is safe care, yaitu merumuskan inovasi strategi penerapan hand hygiene, yaitu untuk petugas kesehatan dengan my five moment for hygiene, yaitu melakukan cuci tangan sebelum bersentuhan dengan pasien, sebelum melakukan prosedur bersih dan steril, setelah bersentuhan dengan cairan tubuh pasien, setellah bersentuhan atau kontak dengan pasien, setelah bersentuhan dengan lingkungan sekitar pasien. Tujuan mencuci tangan diantaranya untuk menghilangkan mikroorganisme yang bersifat sementara yang mungkin dapat ditularkan ke perawat, klien pengunjung, atau tenaga kesehatan lain (Berman, Barry, Evans \& Joel, 2009).

2. Penggunaan Sarung Tangan

Sarung tangan mengurangi risiko petugas kesehatan terkena infeksi bakterial dari pasien, mencegah penularan flora kulit petugas kesehatan kepada pasien, dan mengurangi kontaminasi tangan petugas kesehatan dengan mikroorganisme yang dapat berpindah dari satu pasien ke pasien lainnya (Tietjen, 2004). Semua perawat pelaksana di ruang rawat inap penyakit bedah menggunakan sarung tangan saat menyentuh darah, tinja, urin, cairan tubuh, kontak dengan kulit terluka dan melakukan tindakan invasif. Kenyataan ini sesuai dengan pendapat dari Berman (2009) yang menyatakan bahwa sarung tangan bersih disposible (sekali pakai) harus digunakan untuk melindungi tangan saat perawat memegang objek atau material infektif, seperti; darah, urine, feses, sputum, membran mukosa, kulit yang tidak utuh, dan alat-alat yang telah digunakan). Muhardi (1999), menyebutkan bahwa dalam perawatan luka, sarung tangan harus dipakai sebelum menyentuh sesuatu yang basah (kulit tak utuh, selaput mukosa, darah dan cairan tubuh lain). Gunakan sarung tangan steril untuk prosedur apapun yang akan mengakibatkan kontak dengan jaringan di bawah kulit. William (1983 dalam Potter \& Perry, 2005) yang merekomendasikan bahwa sarung tangan hanya dapat dipergunakan sekali untuk satu tindakan dan atau satu orang pasien. Centers of Disease Control (dalam Potter \& Perry, 2005) juga menganjurkan pemakaian sarung tangan lain setiap berpindah pasien untuk mencegah kontaminasi silang, penggunaan sarung tangan yang sama dan telah mencucinya kembali diantara 
bagian yang kotor bukan tindakan yang aman karena sejumlah bakteri masih ditemukan pada sarung angan maupun pada tangan perawat yang tidak mengganti sarung tangan tersebut.

\section{Penggunaan Masker}

Menurut Potter dan Perry (2005), masker harus digunakan bila diperkirakan ada percikan darah atau cairan tubuh pasien. Selain itu, masker menghindarkan perawat menghirup mikroorganisme dan mencegah penularan pathogen dari saluran pernafasan pasien maupun sebaliknya. Cara memakai dan melepaskan masker juga sudah tepat dilakukan oleh perawat. Masker yang digunakan tepat menutupi hidung dan mulut, metal strip yang ada pada masker juga diatur tepat diatas batang hidung. Penggunaan masker juga hanya untuk sekali pakai dan perawat tidak membiarkan masker yang telah dipakai tergantung di leher tapi langsung membuangnya ke dalam tong sampah. Potter dan Perry (2005), menyebutkan bahwa masker yang dipakai dengan tepat dan terpasang pas akan nyaman menutupi mulut dan hidung sehingga pathogen, darah dan cairan tubuh tidak dapat memasuki atau keluar diantara selaselanya, jika perawat memakai kaca mata, batas atas masker berada tepat di bawah kaca mata sehingga tidak akan mengembun pada kaca mata pada saat perawat menghembuskan nafas.

4. Penggunaan Baju Pelindung

Menurut Tietjen (2004), baju pelindung dipergunakan untuk mencegah cipratan pada baju yang dikenakan oleh petugas pelayanan kesehatan, baju pelindung melindungi petugas pelayanan kesehatan dari kontak dengan darah atau cairan tubuh pasien yang terinfeksi. Sama halnya dengan penggunaan masker, alasan utama menggunakan baju pelindung adalah untuk mencegah perawat kontak langsung dengan bahan, darah atau cairan tubuh yang terinfeksi, alasan lain adalah untuk mencegah pakaian perawat menjadi kotor selama kontak dengan pasien (Potter \& Perry, 2005). Menurut Berman (2009), gaun (dari kain yang bersih) atau disposible (dari bahan sejenis kertas) atau apron (terbuat dari plastik) digunakan saat seragam perawat kemungkinan akan kotor. Baju pelindung harus mempunyai lapisan kedap air sehingga cairan tubuh tidak dapat tembus. Berdasarkan pengamatan, penggunaan baju pelindung yang terbuat dari plastik lebih efektif karena bila kotor bisa dibersihkan lansung dengan menggunakan cairan desinfektan atau alkohol, tetapi bila terbuat dari kain harus diserahkan kepada pihak laundry untuk dilakukan pencucian

5. Penanganan Linen 
Menurut Tietjen (2004), meskipun linen kotor dapat berisi banyak sekali mikroorganisme, hanya sedikit risiko terjadinya kontaminasi silang pada saat memproses linen. Kalau terjadi infeksi yang berhubungan dengan pekerja, seringkali akibat pekerja tidak memakai sarung tangan atau tidak mencuci tangannya selama atau sesudah proses penanganan linen tersebut. Menurut Hegner (2003), linen yang kotor merupakan sumber pathogen dan harus ditangini secara hati-hati, dengan cara menyentuh linen sedikit mungkin untuk mencegah perluasan dan penyebaran mikroorganisme, lipat bagian kotor ke dalam, jangan dikibas-kibaskan atau dihentakkan di dalam ruang perawatan pasien, segera masukkan ke dalam kantong sebelum meninggalkan ruangan. Linen basah diletakkan dalam kantong yang tahan bocor. Centers of Disease Control (dalam Potter \& Perry, 2005), menganjurkan bahwa linen kotor harus diletakkan dalam kontainer tertutup atau kantong plastik untuk mencegah keterceceran.

6. Penanganan Peralatan Perawatan Pasien Menurut Tietjen (2004), persiapan peralatan dan benda-benda lainnya dengan upaya pencegahan infeksi, direkomendasikan melalui tiga langkah pokok yaitu dekontaminasi, pencucian dan pembilasan, desinfeksi tingkat tinggi atau sterilisasi dan penyimpanan. Semua instrumen atau benda-benda perawatan pasien harus dibersihkan sebelum dipergunakan kembali. Metodemetode yang tepat harus digunakan untuk pembersihan peralatan yang digunakan untuk perawatan pasien. Penanganan dan pembuangan instrumen yang tepat sangat penting untuk mencegah penularan infeksi nosokomial ke pasien dan petugas perawatan kesehatan (Schaffer, dkk., 2000). Apabila peralatan yang dipergunakan tidak dalam keadaan mencukupi dan steril, maka sangat berisiko membawa kontaminasi kuman pada saat perawatan (Potter \& Perry, 2005).

7. Kebersihan Lingkungan

Penanganan sampah yang tepat dilingkungan pasien dapat meminimalkan penyebaran infeksi pada petugas kesehatan dan mencegah penularan pada pasien. Jika memungkinkan sampah terkontaminasi harus dikumpulkan dan dipindahkan ke tempat pembuangan dalam wadah tertutup dan anti bocor. Pengelolaan sampah juga dilakukan untuk melindungi petugas pembuangan sampah dari perlukaan (Tietjen, 2004). Dalam pengelolaan limbah, rumah sakit diwajibkan melakukan pemilahan limbah dan menyimpannya dalam kantong plastik yang berbeda-beda berdasarkan karakteristik limbahnya. Limbah domestik dimasukkan ke dalam kantong plastik 
berwarna hitam, limbah infeksius ke dalam kantong plastik berwarna kuning. Pengelolaan limbah medis secara khusus ini dilakukan untuk mencegah dampak negatif terhadap masyarakat dan lingkungan. Pemisahan limbah juga mengurangi jumlah limbah yang harus diolah atau dibakar kemudian dan menurunkan biaya pengelolaan limbah tersebut (Kusminarno, 2004).

8. Penanganan Instrumen Tajam

Menurut Yusran (2008), banyaknya masalah kesehatan dari limbah kesehatan disebabkan oleh benda-benda tajam. Jarum, silet, pisau bedah, dan benda-benda tajam lain dapat menyebabkan terjadinya luka atu infeksi sehingga benda-benda ini harus ditangani dengan sangat hati-hati. Untuk mencegah cedera tertusuk jarum, jangan menutup kembali jarum, membengkokkan dengan sengaja, atau mematahkan jarum dengan tangan, jangan mencabut jarum dari spuit, atau memanipulasi jarum dengan tangan. Letakkan jarum atau spuit ke dalam wadah anti tembus yang diletakkan sedekat mungkin dengan tempat tindakan (Schaffer, dkk. 2000). Tietjen (2004) yang menyatakan bahwa apabila tempat pembuangan jarum dan semprit sekali pakai tidak tersedia di dekat petugas dan perlu menutup kembali penutup jarum, maka gunakan metode penutupan satu tangan. Caranya adalah tempatkan penutup jarum pada permukaan yang rata dan kokoh, kemudian angkat tangan anda, dengan satu tangan memegang semprit, gunakan jarum untuk menyekop tutup tersebut. Dengan penutup di ujung jarum, putar semprit tegak lurus sehingga jarum dan semprit mengarah ke atas. Terakhir dorong penutup jarum untuk menutup ujung jarum sepenuhmya.

9. Kewaspadaan Standar Menurut Tietjen (2004), kewaspadaan standar dibuat untuk semua orang, baik itu pasien dan petugas kesehatan yang mendatangi fasilitas pelayanan kesehatan tanpa menghiraukan diagnosis yang diketahui atau dicurigai. Berlaku untuk darah, semua cairan tubuh, sekresi dan ekskresi, kulit dan selaput lendir yang tidak utuh. Kewaspadaan standar merupakan langkah awal untuk mencegah infeksi nosokomial bagi pasien rawat inap di rumah sakit. Sementara itu, rumah sakit merupakan tempat perawatan penderita yang rentan. Penyebaran atau transmisi mikroba pathogen dari dan ke penderita baik secara langsung maupun tidak langsung dapat terjadi setiap saat dan di setiap unit kerja. Mikroba pathogen tersebut dapat bersumber dari penderita penyakit menular, dari petugas itu sendiri, orang lain yang lalu lalang, peralatan medis, serta lingkungan rumah sakit. Sehingga untuk mengatasi atau memutus rantai penularan tersebut, semua prosedur dan tindakan medis serta perawatan diharuskan 
benarbenar aman dan bebas dari keberadaan mikroba pathogen sesuai dengan kewaspadaan standar (Darmadi, 2008). Florence Nightingale (di kutip dari Thomey, 1994) yang mengemukakan bahwa keperawatan berarti memanipulasi faktor-faktor lingkungan sehingga dapat menyembuhkan pasien. Perawat harus memberikan lingkungan yang bersih, nyaman dan aman sebagai tempat pasien memulihkan diri. Kebersihan seperti sebuah konsep kritis lain dalam teori lingkungan Nightingale mengkhususkan terhadap tempat tinggal pasien, perawat dan lingkungan fisik. Nightingale melihat bahwa lingkungan yang kotor merupakan sumber infeksi yang mengandung bahan organik. Meskipun lingkungan dengan ventilasi yang baik, adanya material organik membuat area menjadi kotor. Oleh karena itu, penanganan yang tepat dan pembuangan kotoran dan limbah yang tepat dapat mencegah kontaminasi lingkungan.

10. Peran kepemimpinan

Perawat mencegah terjadinya infeksi dengan cara memutuskan rantai penularan infeksi (Craven \& Hirnle, 2007). Kegiatan ini berkaitan dengan perilaku perawat. Perilaku perawat dalam melakukan kegiatan pencegahan dan pengendalian infeksi dapat dibentuk dengan aktivitas dalam menampilkan peran dan fungsi kepala ruang sebagai pemimpin. Kepemimpinan kepala ruang dapat memengaruhi perilaku bawahannya (Robbins, 2003; Sellgren, Ekval, \& Tomson, 2006). Manajemen kepala ruang sangat penting dalam menunjang program pencegahan dan pengendalian infeksi di rumah sakit. Salah satu fungsi manajemen adalah pengorganisasian, dimana kepala ruang hendaknya mengembangkan organisasi keperawatan secara objektif sehingga memudahkan perawat dalam melaksanakan asuhan keperawatan khususnya upaya pencegahan dan pengendalian infeksi. Perilaku perawat dapat ditunjukkan dengan peningkatan kinerja dan kepatuhan perawat dalam melakukan kegiatan pencegahan dan pengendalian infeksi. Efstathiou, Papastavrou, Raftopoulos, dan Merkouris (2011) menyatakan perubahan perilaku perawat dipengaruhi oleh pengetahuan dan kepatuhan perawat terhadap pelaksanaan standard precaution.

\section{Penutup}

\section{Kesimpulan}

Beberapa cara yang dilakukan perawat dalam memutus rantai infeksi yaitu berupa mencuci tangan, penggunaan sarung tangan, penggunaan masker, penggunaan baju pelindung, 
penanganan linen, penanganan peralatan perawatan pasien, kebersihan lingkungan, penanganan instrumen tajam, kewaspadaan standard dan peran kepala ruangan.

\section{Saran}

Peran perawat sangat penting, tidak hanya sebagai pemberi layanan namun juga sebagai edukator, mengingat banyaknya faktor penyebab terjadinya infeksi nosokomial di dalam rumah sakit. Oleh karena itu perawat diharapkan harus benar benar menerapkan prosuder dalam memutus rantai infeksi.

\section{Daftar Pustaka}

Alifariki, L. O. (2019). Hubungan Pelaksanaan Program Pencegahan Dan Pengendalian Infeksi Terhadap Perilaku Perawat Dalam Pencegahan Dan Pengendalian Infeksi Nosokomial Ruang Rawat Inap RSUD Kota Kendari. Manuju: Malahayati Nursing Journal, 1(2), 148-150.

Dewi, F., Hanny, H., \& Kuntarti. (2016). Memutus Rantai Infeksi Melalui Fungsi Pengorganisasian Kepala Ruang Rawat. Jurnal Keperawatan Indonesia, 19(2), 107-108.

Fildzah, A. M., \& Siti, M. (2017). Determinan Infeksi Nosokomial Pada Pasien di Rumah Sakit Pusat Pertamina Tahun 2017. Jurnal Kesehatan Masyarakat, 1(1), 1-3.

Hutahaean, S., \& Hanny, H. (2018). Pengembangan Fungsi Dan Peran Kepala Ruangan Dalam Pencegahan Dan Pengendalian Infeksi Di Rumah Sakit X. Jurnal Akademi Keperawatan Husada Karya Jaya, 4(1), 54-55.

Kamil, H. (2011). Penerapan Prinsip Kewaspadaan Standar Oleh Perawat Pelaksana Di Ruang Rawat Inap Penyakit Bedah RSUDZA Banda Aceh. Idea Nursing Journal, 2(1), 2-10.

Lestari, E. P., Abdul, m., \& Andreanda, N. (2018). Faktor-Faktor Yang Mempengaruhi Layanan Promosi Kesehatan Pada Pasien Tuberkulosis Paru Di Ruang Eboni Lantai 3 RS PMI Bogor Tahun 2017. (2018). Jurnal Mahasiswa Kesehatan Masyarakat, 1(1), 45-46.

Madjid, T., \& Adik, W. (2017). Analisis Penerapan Dan Pengendalian Infeksi Di Ruang Rawat Inap RSUD Tebet Tahun 2017. Jurnal Arsi, 4(1), 57-59.

Nurseha, D. (2013). Pengembangan Tindakan Pencegahan Infeksi Nosokomial Oleh Perawat Di Rumah Sakit Berbasis Health Belief Model. Jurnal Ners, 8(1), 64-65.

Ritonga, E. P. (2017). Pelaksanaan Five Moment Hand Hygiene Di Ruang Rawat Inap Rumah Sakit Swasta Kota Medan. Jurnal IImiah Keperawatan Imelda, 3(2), 172-176.

Riyadi, S., \& Rina, K. (2018). Efektivitas Penerapan Cuci Tangan Disinfeksi Dalam Meningkatkan Kepatuhan Pencegahan Dan Pengendalian Infeksi Silang Di Laboratorium Pelayanan Kesehatan Gigi Dan Mulut. Jurnal Bahan Kesehatan Masyarakat, 2(2), 139-140.

Simamora, R. H. (2019). Pengaruh Penyuluhan Identifikasi Pasien dengan Menggunakan Media Audiovisual terhadap Pengetahuan Pasien Rawat Inap. Jurnal Keperawatan Silampari, 3(1), 342-351.

Simamora, R. H. (2020). Learning of Patient Identification in Patient Safety Programs Through Clinical Preceptor Models. Medico Legal Update, 20(3), 553-556. 
